\title{
Phenotypic and molecular characterization of $\beta$-lactamase and plasmid-mediated quinolone resistance genes in Klebsiella oxytoca isolated from slaughtered pigs in Thailand
}

\author{
Nattamol Phetburom ${ }^{1}$ (D), Parichart Boueroy ${ }^{1}$ (D), Peechanika Chopjitt ${ }^{10}$, Rujirat Hatrongjit ${ }^{\mathbb{D}}$, \\ Suphachai Nuanualsuwan ${ }^{3}$ id and Anusak Kerdsin ${ }^{1}$ (D)
}

\begin{abstract}
1. Department of Community Health, Faculty of Public Health, Kasetsart University, Chalermphrakiat Sakon Nakhon Province Campus, Sakon Nakhon, Thailand; 2. Department of General Sciences, Faculty of Science and Engineering, Kasetsart University, Chalermphrakiat Sakon Nakhon Province Campus, Sakon Nakhon, Thailand; 3. Department of Veterinary Public Health, Faculty of Veterinary Science, Chulalongkorn University, Bangkok, Thailand.

Corresponding author: Parichart Boueroy, e-mail: parichart.bou@ku.th

Co-authors: NP: nattamol.phet@ku.th,PC: peechanika.c@ku.th,RH: rujirat.ha@ku.th, SN: suphachai.n@chula.ac.th, AK: anusak.ke@ku.th

Received: 04-10-2021, Accepted: 12-01-2022, Published online: 13-02-2022
\end{abstract}

doi: www.doi.org/10.14202/vetworld.2022.309-315 How to cite this article: Phetburom N, Boueroy P, Chopjitt P, Hatrongjit R, Nuanualsuwan S, Kerdsin A (2022) Phenotypic and molecular characterization of $\beta$-lactamase and plasmidmediated quinolone resistance genes in Klebsiella oxytoca isolated from slaughtered pigs in Thailand, Veterinary World, 15(2): 309-315.

\begin{abstract}
Background and Aim: Over recent years, antimicrobial-resistant Klebsiella species in humans, animals, food animals, food products, and agricultural environments have been the center of attention due to its role in the evolution of antimicrobial resistance. The emergence of resistance to fluoroquinolones and cephalosporins of third and higher generations in Klebsiella oxytoca has not received much attention in animal husbandry compared to that in Klebsiella pneumoniae. Reports on K. oxytoca are limited in the study area. Therefore, we investigated the antimicrobial susceptibility and resistance genes in K. oxytoca isolated from slaughtered pigs in Thailand.
\end{abstract}

Materials and Methods: Microbiological examination was conducted on 384 Klebsiella spp. isolates recovered from slaughtered pigs in ten provinces of Thailand. Seventy-two K. oxytoca isolates $(18.75 \%)$ were examined for antimicrobialresistant genes $\left(\beta\right.$-lactamase $\left[b l a_{\mathrm{TEM}}, b l a_{\mathrm{CTX}-\mathrm{M}}\right.$, and $\left.\left.b l a_{\mathrm{SHV}}\right]\right)$ and fluoroquinolone-resistant genes $(q n r A, q n r B, q n r C, q n r D$, qnrS, oqxAB, aac(6')-Ib-cr, and qepA).

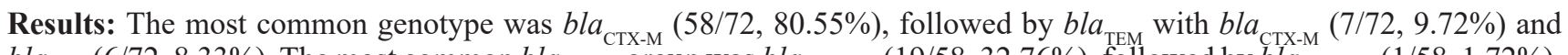
$b_{l a}(6 / 72,8.33 \%)$. The most common $b_{\text {TEM }}\left(a_{\text {СТХ-м }}\right.$ group was bla ${ }_{\text {СТХ-М-1 }}(19 / 58,32.76 \%)$, followed by $b l a{ }_{\text {СТХ-м-9 }}(1 / 58,1.72 \%)$. Plasmid-mediated quinolone resistance genes were identified in $13(18.05 \%)$ isolates: qnrS (16.70\%) and qnrB (1.4\%). All 13 isolates had $q n r S$ transferable to an Escherichia coli recipient, whereas qnrB was not detected in any transconjugants. Either bla $a_{\mathrm{CTX}-\mathrm{M}}$ or bla $\mathrm{TEM}_{\mathrm{TEM}}$ harbored by one $K$. oxytoca strain was transferable to an $E$. coli recipient. Analysis of antimicrobial susceptibility revealed that more than $90 \%$ of the bla $a_{\text {СТХ-М }}$-carrying $K$. oxytoca isolates were susceptible to chloramphenicol, trimethoprim, ceftazidime, cefepime, cefotaxime, amoxicillin-clavulanic acid, piperacillin-tazobactam, and fosfomycin. All $K$. oxytoca isolates (13) harboring qnr were susceptible to carbapenem and ceftriaxone; however, 43 (74.13\%) of the $K$. oxytoca isolates harboring bla ${ }_{\text {СТХ-М }}$ exhibited extended-spectrum $\beta$-lactamase activity. Most of the $K$. oxytoca isolates from pigs were highly resistant to ampicillin, azithromycin, and gentamicin.

Conclusion: To prevent further transmission of Klebsiella spp. between food animals and humans, strict control of antibiotic use in clinical and livestock settings is necessary along with routine disinfection of the livestock environment and efforts to increase awareness of antimicrobial resistance transmission.

Keywords: Klebsiella oxytoca, plasmid-mediated quinolone resistance, slaughtered pigs, Thailand, $\beta$-lactamase.

\section{Introduction}

Extended-spectrum $\beta$-lactamase (ESBL) was first isolated from Klebsiella species and later from Escherichia coli, Pseudomonas aeruginosa, Serratia marcescens, and other Gram-negative bacilli [1,2]. ESBL can confer resistance to a variety of $\beta$-lactam

Copyright: Phetburom, et al. Open Access. This article is distributed under the terms of the Creative Commons Attribution 4.0 International License (http://creativecommons.org/licenses/ by/4.0/), which permits unrestricted use, distribution, and reproduction in any medium, provided you give appropriate credit to the original author(s) and the source, provide a link to the Creative Commons license, and indicate if changes were made. The Creative Commons Public Domain Dedication waiver (http:// creativecommons.org/publicdomain/zero/1.0/) applies to the data made available in this article, unless otherwise stated. antibiotics, including penicillins and broad-spectrum cephalosporins with an oxyimino side chain, such as cefotaxime, ceftriaxone, and ceftazidime, but not often to carbapenems or cephamycins, such as cefoxitin [3]. ESBL-producing Gram-negative bacilli have rapidly spread and become a serious threat to human health worldwide, resulting in significant morbidity and mortality [4]. Various types of $\beta$-lactamase genes (including ESBL genes), such as $b l a_{\text {СТХ-М }}, b l a_{\mathrm{SHV}}$, and bla $_{\mathrm{TEM}}$, have been reported in $K$. oxytoca strains obtained from patients and healthy persons [5]. Within the bla ${ }_{\text {СТХ-м }}$ family, bla ${ }_{\text {СТХ-М-2 }}$-carrying $K$. oxytoca strains have been identified in milk samples obtained from cows with mastitis in Japan [6]. In a study 
conducted in Italy, $b l a_{\text {CTX-M-9 } 9}, b l a_{\text {SHV-12}}$, and $b l a_{\text {DHA-1 }}$ genes were detected in K. oxytoca isolates [7].

Plasmid-mediated resistance to quinolones (PMQR) genes, including qnrA, qnrB, qnrS, qnrC, and $q n r D$ genes, has been demonstrated to play a significant role in quinolone resistance by protecting DNA gyrase and topoisomerase IV from the inhibitory activity of quinolones $[8,9]$. Aminoglycoside acetyltransferase $\left(a a c\left(6^{\prime}\right)-I b-c r\right)$ gene has been shown to enzymatically modify fluoroquinolones [9]. The production of efflux pumps is enhanced by qep $A, \operatorname{acr} A B$, and $o q x A B$ genes, which also contribute to quinolone and fluoroquinolone resistance [10]. Klebsiella oxytoca isolated from cats and dogs in Italy were positive for $q n r$ genes (qnrAl and qnrB4), and one K. oxytoca isolate was positive for the $a a c\left(6^{\prime}\right)-I b-c r$ gene [7].

The spread of $K$. ocytoca strains carrying $\beta$-lactamase and PMQR genes may be a threat to the "One Health" program. In Thailand, where antibiotics are used without restriction in the healthcare, livestock, and food production sectors, research on the epidemiology of antibiotic-resistant bacteria in food animals and its associated public health implications has been conducted in common bacteria, such as E. coli, Klebsiella pneumoniae, and Salmonella spp.

However, reports on $K$. oxytoca are limited in the study area. Therefore, we investigated the antimicrobial susceptibility and resistance genes in $K$. oxytoca isolated from slaughtered pigs in Thailand.

\section{Materials and Methods \\ Ethical approval}

Ethical review and approval were not required for this study as the samples were collected from slaughtered pigs at the slaughterhouses as per standard collection procedure.

\section{Study period and location}

The study was conducted from October 2014 to September 2015. The sampling locations were the slaughterhouses in 10 provinces nationwide: Bangkok, Nakhon Pathom, Lop Buri, Chiang Mai, Lampang, Chon Buri, Roi-Et, and Khon Kaen. Surat Thani, and Songkhla (Figure-1).

\section{Bacterial isolates and identification}

We followed the procedures for isolation and identification of Klebsiella spp. as described by Phetburom et al. [11]. We recovered 384 isolates of Klebsiella spp. from slaughtered pigs. Four slaughterhouses were randomly selected from each province, and 50 carcass surface swab samples were randomly collected from each slaughterhouse, which results in a sample size of 2000 swab samples. Using a single swab for each carcass, $400 \mathrm{~cm}^{2}$ of one side of the carcass was swabbed. The swab samples were immediately stored on ice in zip-lock bags and transported to the microbiological laboratory. Isolation and identification of Klebsiella spp. were performed using 10 -fold serial dilutions of swab samples achieved using buffered peptone water (BPW; pH 7.2). Each diluted BPW sample was spread onto MacConkey agar (Difco Laboratories, Detroit, Mich. USA) and incubated at $37^{\circ} \mathrm{C}$ for $24 \mathrm{~h}$. The presumptive identification of Klebsiella species was confirmed using conventional biochemical tests, including motility, Voges-Proskauer, ornithine decarboxylation, lysine decarboxylation, malonate, and O-nitrophenyl- $\beta$ D-galactopyranoside [12]. In total, 384 Klebsiella isolates were recovered and all isolates were stored at $-80^{\circ} \mathrm{C}$ in a laboratory freezer until use in this study. The presumptive Klebsiella species for up to five colonies were cultured on MacConkey agar (Difco Laboratories) and their DNA was prepared using ZymoBIOMICS ${ }^{\text {TM }}$ DNA Miniprep Kits (Zymo Research Corp., CA, USA) according to the manufacturer's protocols. Polymerase chain reaction (PCR) was performed using a thermal cycler to identify $K$. oxytoca, as described elsewhere [13]. The PCR program included initial denaturation at $95^{\circ} \mathrm{C}$ for $3 \mathrm{~min}$, 30 cycles of denaturation at $95^{\circ} \mathrm{C}$ for $30 \mathrm{~s}$, annealing at $55^{\circ} \mathrm{C}$ for $45 \mathrm{~s}$, extension at $72^{\circ} \mathrm{C}$ for $1 \mathrm{~min}$, and a final cycle of amplification at $72^{\circ} \mathrm{C}$ for $7 \mathrm{~min}$.

\section{Detection of $\beta$-lactamase genes}

Isolates carrying $\beta$-lactamase genes $\left(b l a_{\mathrm{TEM}}, b l a_{\mathrm{C}-}\right.$ TX-M, and $b l a_{\mathrm{SHV}}$ ) were detected through multiplex PCR using a thermal cycler with a PCR program that included initial denaturation at $95^{\circ} \mathrm{C}$ for $3 \mathrm{~min}, 30$ cycles of denaturation at $95^{\circ} \mathrm{C}$ for $30 \mathrm{~s}$, annealing at $55^{\circ} \mathrm{C}$ for $30 \mathrm{~s}$, extension at $72^{\circ} \mathrm{C}$ for $1 \mathrm{~min}$, and amplification at $72^{\circ} \mathrm{C}$ for 7 min [14]. The bla ${ }_{\text {СТX-M }}$-harboring $K$. oxytoca was classified into CTX-M groups (bla $a_{\text {CTX-M-1 }}$, bla $a_{\text {CTX-M-2 }}$, $b l a_{\text {CTX-M-5 }}, b l a_{\text {CTX-M-8 } 8}, b l a_{\text {CTX-M-99 }}$, and $b l a_{\text {CTX-M-25 }}$ groups) using multiplex PCR [15]. PCR amplification was performed using a thermal cycler with a PCR program of denaturation at $94^{\circ} \mathrm{C}$ for $5 \mathrm{~min}, 30$ cycles of denaturation at $94^{\circ} \mathrm{C}$ for $25 \mathrm{~s}$, annealing at $52^{\circ} \mathrm{C}$ for $40 \mathrm{~s}$, extension at $72^{\circ} \mathrm{C}$ for $50 \mathrm{~s}$, and amplification at $72^{\circ} \mathrm{C}$ for $6 \mathrm{~min}$.

\section{Detection of plasmid-mediated quinolone resistance genes}

PMQR genes (qnrA, qnrB, qnrC, qnrD, qnrS, $o q x A B, a a c\left(6^{\prime}\right)-I b-c r$, and $q e p A$ ) were determined using multiplex PCR [16]. PCR amplification was performed using a thermal cycler with a PCR program of denaturation at $95^{\circ} \mathrm{C}$ for $3 \mathrm{~min}, 30$ cycles of denaturation at $95^{\circ} \mathrm{C}$ for $30 \mathrm{~s}$, annealing at $63^{\circ} \mathrm{C}$ for $90 \mathrm{~s}$, extension at $72^{\circ} \mathrm{C}$ for $90 \mathrm{~s}$, and amplification at $72^{\circ} \mathrm{C}$ for $10 \mathrm{~min}$.

\section{Antimicrobial susceptibility testing}

$K$. oxytoca isolates harboring bla $a_{\mathrm{CTX- \textrm {M }}} q n r S$, or $q n r B$ were further investigated for antimicrobial susceptibility using the disk diffusion method according to the 2021 Clinical and Laboratory Standards Institute guidelines [17]. The antimicrobial disks used in the assay were loaded with ampicillin $(10 \mu \mathrm{g})$, gentamicin $(10 \mu \mathrm{g})$, amikacin $(30 \mu \mathrm{g})$, amoxicillin-clavulanic acid $(30 \mu \mathrm{g})$, piperacillin-tazobactam $(110 \mu \mathrm{g})$, ceftriaxone $(30 \mu \mathrm{g})$, cefepime $(30 \mu \mathrm{g})$, cefotaxime $(30 \mu \mathrm{g})$, 


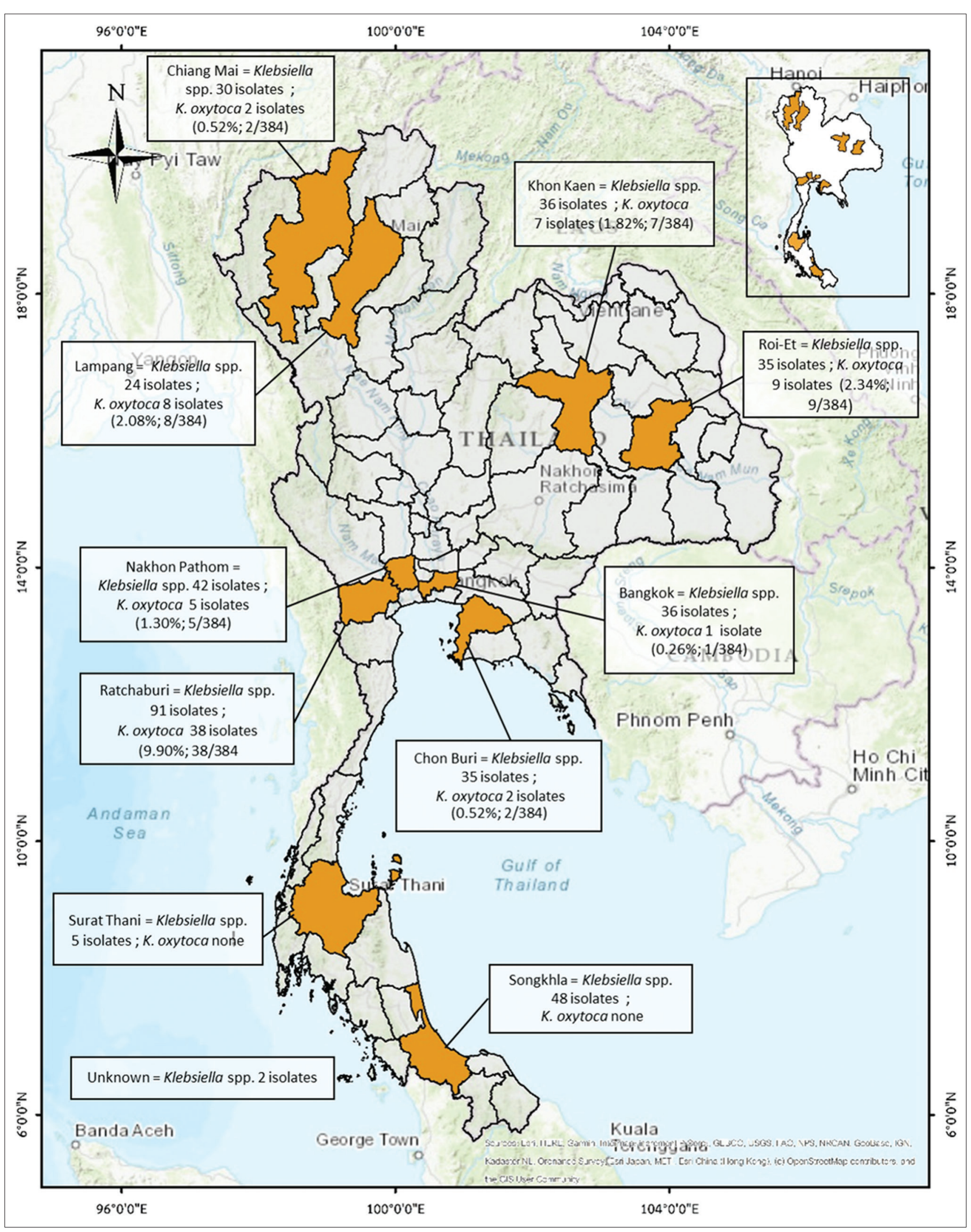

Figure-1: Locations for samples collection from slaughterhouses in 10 provinces nationwide: Bangkok, Nakhon Pathom, Lop Buri, Chiang Mai, Lampang, Chon Buri, Roi-Et, Khon Kaen, Surat Thani, and Songkhla [Source: A geographical information system (GIS) software QGIS (version 2.18.28) was used to create a study map].

ceftazidime $(30 \mu \mathrm{g})$, ertapenem $(10 \mu \mathrm{g})$, imipenem $(10$ $\mu \mathrm{g})$, meropenem $(10 \mu \mathrm{g})$, ciprofloxacin $(5 \mu \mathrm{g})$, levofloxacin $(5 \mu \mathrm{g})$, chloramphenicol $(30 \mu \mathrm{g})$, tetracycline
$(30 \mu \mathrm{g})$, fosfomycin $(200 \mu \mathrm{g})$, nitrofurantoin $(300 \mu \mathrm{g})$, azithromycin $(5 \mu \mathrm{g})$, or trimethoprim $(5 \mu \mathrm{g})$. E. coli ATCC 25922 was used as the control. 
Detection of ESBL production based on combination disk test

The production of ESBL was tested for in 58 bla ${ }_{\text {СтХ-M }}$-harboring $K$. oxytoca isolates using the combined disk method and separate commercial disks containing cefotaxime $(30 \mu \mathrm{g})$ and ceftazidime $(30 \mu \mathrm{g})$ with or without clavulanic acid $(10 \mu \mathrm{g})$ [17]. An increase in zone size $\geq 5 \mathrm{~mm}$ for cefotaxime and ceftazidime with or without clavulanic acid was considered to indicate ESBL production [17].

\section{Detection of ESBL Nordmann-Dortet-Poirel (NDP) assay}

The bla ${ }_{\text {СТХ-м }}$-harboring $K$. oxytoca isolates were tested for extended-spectrum $\beta$-lactamase activity using the ESBL NDP assay [18]. One calibrated inoculated loop $(10 \mu \mathrm{L})$ of the tested strain was briefly suspended in $100-\mu \mathrm{L}$ B-PER II ${ }^{\circledR}$ Bacterial Protein Extraction Reagent (Thermo Scientific, USA) buffer and centrifuged at room temperature for $5 \mathrm{~min}$. The supernatant $(30 \mu \mathrm{m})$ was mixed with $100 \mu \mathrm{L}$ of a $1-\mathrm{mL}$ solution of $\mathrm{pH} 7.8$ phenol red solution with or without $6 \mathrm{mg}$ of purified cefotaxime sodium salt (Tokyo Chemical Industry Co., Ltd, Japan), incubated at $37^{\circ} \mathrm{C}$ for $2 \mathrm{~h}$, and observed for color change. Extendedspectrum $\beta$-lactamase-producing strains were identified as they broke down cefotaxime into acidic products, changing the color of the phenol red indicator to yellow.

\section{Conjugation assay}

Conjugation assays were performed using all isolates of $K$. oxytoca harboring bla ${ }_{\text {СтХ-м }}$ and qnrS as donors and streptomycin-resistant E. coli UB1637 as recipients, as described elsewhere [19]. MuellerHinton agar plates supplemented with $3200 \mu \mathrm{g} / \mathrm{mL}$ of streptomycin were used to select transconjugants. Transconjugants were confirmed as E. coli using PCR [20], and PCR was used to determine the presence of ESBL and PMQR genes.

\section{Results}

\section{Detection of $\boldsymbol{\beta}$-lactamase gene in $\boldsymbol{K}$. oxytoca}

Of the 384 Klebsiella spp., 72 were identified as $K$. oxytoca $(18.75 \%)$ using PCR (Figure-1). In all $K$. oxytoca isolates, bla ${ }_{\mathrm{TEM}}, b_{\text {CTX-M }}$, and bla $a_{\mathrm{SHV}}-\beta$-lactamase genes were detected. We detected 64 isolates (88.89\%) carrying $\beta$-lactamase genes. Among these, the majority only carried bla ${ }_{\text {СтХ-м }}(51 / 72,70.83 \%)$, and seven carried $b l a_{\text {TЕм }}$ and $b l a_{\text {СТХ-м }}$ genes $(7 / 72$, $9.72 \%$ ), as presented in Table-1. Of the 58 isolates of bla ${ }_{\mathrm{CTX}-\mathrm{M}}$-harboring $K$. oxytoca (51 carrying only bla $a_{\text {СТХ-M }}$ and 7 carrying $b l a_{\text {СТХ-M }}$ and another resistance gene), $32.76 \%$ carried bla ${ }_{\text {СТХ-М-1 }}(19 / 58), 1.72 \%$ carried bla $a_{\text {СТХ-м-9 }}(1 / 58)$, and $65.52 \%$ carried $b l a_{\text {СТХ-М }}$ of an unknown group (38/58), as presented in Table-1.

\section{Detection of plasmid-mediated quinolone resistance} genes

Among the PMQR genes detected, qnrS was found in $16.67 \%(12 / 72)$ of $K$. oxytoca isolates (Table-1). One isolate had $q n r B(1.4 \%)$. Of the 12 $q n r S$-carrying isolates, 8 had only $q n r S, 2$ had $q n r S$ and $b l a_{\text {Стх }}$ of an unknown group, and 2 had $q n r S$ and $b_{\text {TEM }}$ (Table-1).

\section{Transferability of $\beta$-lactamase and PMQR genes}

The $61 \mathrm{~K}$. oxytoca isolates carrying bla ${ }_{\text {СтХ-м }}, q n r$, or both were subjected to conjugation assay using streptomycin-resistant $E$. coli UB1637 as the recipient. Not all $K$. oxytoca donors carrying only bla $a_{\text {CTX-M }}(\mathrm{n}=50)$ transferred resistance to recipient $E$. coli cells. On the contrary, $K$. oxytoca isolates carrying only qnr $S(\mathrm{n}=8)$ and those harboring either qnrS with bla ${ }_{\text {СтХ-м }}$ or $q n r S$ with bla ${ }_{\mathrm{TEM}}(\mathrm{n}=4)$ successfully transferred resistance to recipient $E$. coli (Table-2). Among these transconjugants, $q n r S, q n r S$ with $b l a_{\text {CTX-M }}$, and $q n r S$ with $b l a_{\text {TEM }}$ were successfully transferred, whereas $q n r B$ was not detected in any of the transconjugants in this study (Table-2).

\section{Antimicrobial susceptibility testing}

A total of 20 antimicrobial agents were tested on $61 \mathrm{~K}$. oxytoca isolates harboring bla ${ }_{\text {СтХ-М }}$ and/or $q n r S$ genes. All isolates were susceptible to carbapenems (ertapenem, imipenem, and meropenem) and ceftriaxone (Figure-2 and Table-3). More than 90\% of $K$. oxytoca isolates were susceptible to chloramphenicol, trimethoprim, ceftazidime, cefepime, cefotaxime, amoxicillin-clavulanic acid, piperacillin-tazobactam, and fosfomycin. Almost all $K$. oxytoca isolates were highly resistant to ampicillin $(98.36 \%)$ and azithromycin $(96.72 \%)$. Resistance was also recorded to gentamicin $(52.46 \%)$, amikacin $(31.15 \%)$, ciprofloxacin $(19.67 \%)$, tetracycline $(14.75 \%)$, nitrofurantoin (9.84\%), and levofloxacin (14.75\%), as presented in Figure-2 and Table-3. An ESBL-producing phenotype based on the combination disk test showed that $100 \%$ of bla ${ }_{\text {СТХ-м- }}$ carrying $K$. oxytoca were non-ESBL producers. The ESBL NDP assays revealed that $74.13 \%$ $(43 / 58)$ of the $K$. oxytoca isolates harboring bla

Table-1: Characterization of antimicrobial resistance genes in 72 Klebsiella oxytoca isolated from slaughtered pigs in Thailand.

\begin{tabular}{|c|c|c|c|c|c|c|c|}
\hline \multirow[t]{3}{*}{ Species } & \multicolumn{5}{|c|}{$\beta$-lactamase genes $(\%)$} & \multicolumn{2}{|c|}{ PMQR (\%) } \\
\hline & \multicolumn{3}{|c|}{$\beta$-lactamase genes ( $\%)$} & \multicolumn{2}{|c|}{ CTX-M group (\%) } & & \\
\hline & $b^{b} a_{T E M}$ & bla $_{\text {cTX-M }}$ & $b / a_{T E M}+b / a_{C T X-M}$ & Group 1 & Group 9 & qne $S$ & qnr B \\
\hline Klebsiella oxytoca & $6(8.33)$ & $51(70.83)$ & $7(9.72)$ & $19(32.76)$ & $1(1.72)$ & $12(16.67)$ & $1(1.38)$ \\
\hline
\end{tabular}

$\mathrm{PMQR}=$ Plasmid-mediated quinolone resistance 


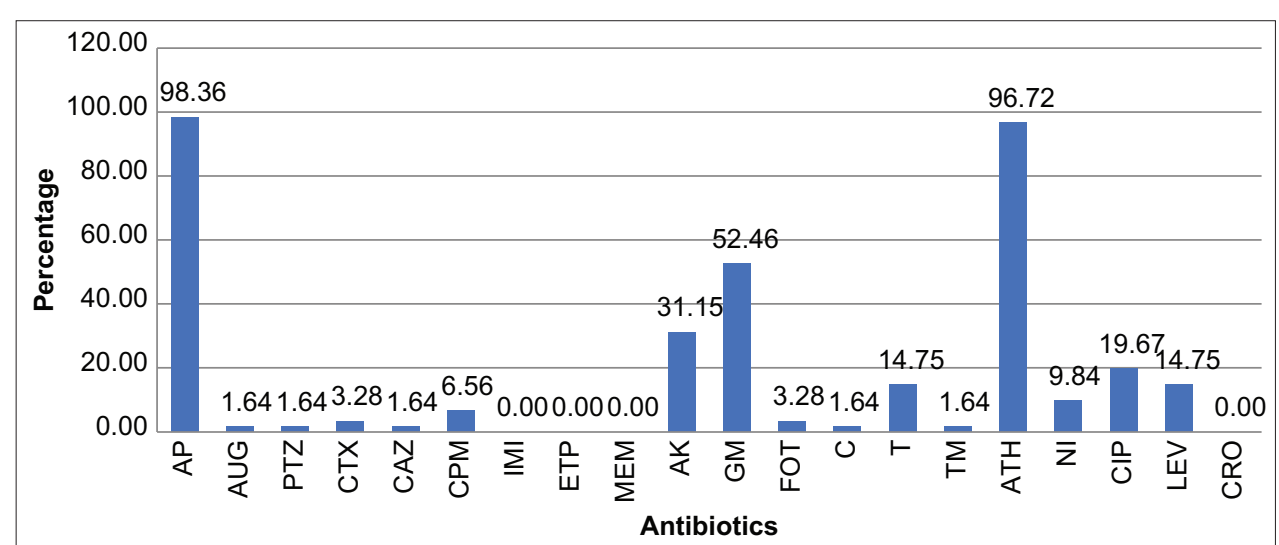

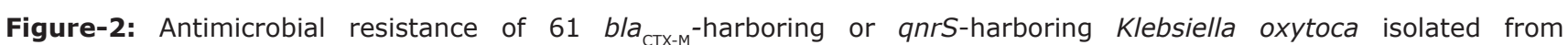
slaughtered pigs. Antimicrobial resistance of 61 blaCTX-M-harboring or qnrS-harboring Klebsiella oxytoca isolated from slaughtered pigs. AP=Ampicillin, $\mathrm{GM}=$ Gentamicin, AK=Amikacin, AUG=Amoxicillin/clavulanic acid, PTZ=Piperacillintazobactam, CPM=Cefepime, CTX=Cefotaxime, CIP=Ciprofloxacin, LEV=Levofloxacin, ETP=Ertapenem, IMI=Imipenem, MEM=Meropenem, $\quad \mathrm{CRO}=$ Ceftriaxone,$\quad \mathrm{CAZ}=$ Ceftazidime,$\quad \mathrm{C}=$ Chloramphenicol, $\mathrm{T}=$ Tetracycline, FOT=Fosfomycin, $\mathrm{NI}=$ Nitrofurantoin, $\mathrm{ATH}=$ Azithromycin, $\mathrm{TM}=$ Trimethoprim.

Table-2: Characteristics and antimicrobial resistance profiles of donor and transconjugant of 13 Klebsiella oxytoca harboring PMQR genes.

\begin{tabular}{|c|c|c|c|}
\hline \multirow[t]{2}{*}{ ID } & \multirow{2}{*}{$\begin{array}{l}\text { Pattern of PMQR } \\
\text { donor }\end{array}$} & \multicolumn{2}{|c|}{ Gene transfer } \\
\hline & & $\beta$-lactamases & PMQR \\
\hline 19 RB 111.1 & qnrS & - & qnrS \\
\hline 26 RB 116.2 & $b^{\prime} / a_{\mathrm{TEM}}+b l a_{\mathrm{CTX}-\mathrm{M}}+q n r S$ & - & qnrs \\
\hline $1 \mathrm{KK} 1.2$ & $b / a_{\mathrm{TEM}}+q n r S$ & $b^{b l a} a_{\mathrm{TEM}}$ & qnrs \\
\hline $60 \mathrm{KK} 111.3$ & $b / a_{\mathrm{TEM}}+q n r S$ & bla $_{\mathrm{TEM}}$ & qnrs \\
\hline 33 LP 36.3 & bla & - & qnrS \\
\hline 41 LP 45.3 & bla ${ }_{\text {CTX-M }}+q n r S$ & - & qnrS \\
\hline 44 LP 53.2 & bla $_{\text {CTX-M }}+q n r S$ & - & qnrS \\
\hline 47 LP 51.2 & bla $_{\text {CTX-M }}+q n r S$ & bla $a_{\text {CTX-M }}$ & qnrs \\
\hline 50 LP 54.2 & bla ${ }_{\text {СТX-M }}+q n r S$ & - & qnrS \\
\hline 51 LP 55.2 & bla $_{\mathrm{CTX}-\mathrm{M}}+q n r B$ & - & - \\
\hline 54 LP 61.1 & bla $_{\text {СТX-м }}+q n r S$ & bla ${ }_{\mathrm{CTX}-\mathrm{M}}$ & qnrS \\
\hline 61 LP 54.2 & bla & $-\quad(1 x-m$ & qnrS \\
\hline $35 \mathrm{CM} 72.2$ & bla $_{\text {CTX-м }}+q n r S$ & - & qnrs \\
\hline Total & & $\begin{array}{l}4 \\
(30.77 \%)\end{array}$ & $\begin{array}{l}12 \\
(92.31 \%)\end{array}$ \\
\hline
\end{tabular}

$\mathrm{PMQR}=$ Plasmid-mediated quinolone resistance

exhibited $\beta$-lactamase activity. Of the $13 q n r S-$ and qnrB-harboring $K$. oxytoca isolates, $9(69.23 \%)$ showed resistance to fluoroquinolone: About $66.67 \%$ for ciprofloxacin $88.88 \%$ for levofloxacin and $55.56 \%$ for both.

\section{Discussion}

Our study revealed that the majority of $\beta$-lactamase-carrying $K$. oxytoca isolates possessed $b l a_{\text {СTX-M }}$, especially $b l a_{\text {CTX-M-1 }}$. In the current study, we did not detect bla $_{\mathrm{SHV}}$. The dissemination of bla ${ }_{\mathrm{CTX- \textrm {M } - 2}}$ among $K$. oxytoca isolates collected from pigs has been reported [21,22], and $b l a_{\mathrm{CTX}-\mathrm{M}-15}$ and $b l a_{\mathrm{TEM}-1}$ were detected in $K$. oxytoca isolates collected from six provinces in China [23]. K. oxytoca isolates harboring $b l a_{\text {CTX-M }}$ were highly susceptible to cefotaxime, ceftazidime, and cefepime (93.1-98.3\%) and 100\% susceptible to ceftriaxone. Combination disk assay revealed that they were non-ESBL producers; however, ESBL NDP assay demonstrated that 43 (74.1\%) of these isolates exhibited $\beta$-lactamase activity on cefotaxime. Another study observed that $K$. oxytoca showed ostensibly positive resistance to cefotaxime and cefepime and rare resistance to ceftazidime, with only borderline resistance to these cephalosporins (MIC 2-8 mg/L), suggesting that there was hyperproduction of K1 (KOXY) chromosomal $\beta$-lactamase rather than ESBL production [24]. The positive result for ESBL NDP assay but the negative result for combination disk assay seen in our study may suggest the presence of $\mathrm{K} 1 \beta$-lactamase in this organism.

The current study indicated that $K$. oxytoca isolated from slaughtered pigs was highly susceptible to cefoxitin (96.72\%), ceftazidime (98.36\%), and cefepime (93.44\%). Hossain et al. [25] reported that $K$. oxytoca strains isolated from pet turtles in Korea were highly susceptible to cefoxitin $(81.25 \%)$, ceftazidime $(80.00 \%)$, and cefepime $(80.77 \%)$, and based on antimicrobial susceptibility testing results, $98.3 \%$ of the $K$. oxytoca strains were resistant to ampicillin. Klebsiella spp., especially K. pneumoniae and K. oxytoca, produce different chromosomal $\beta$-lactamases, leading to natural resistance to penicillins [26].

In the current study, $q n r S$ and $q n r B$-harboring $K$. oxytoca strains were widely distributed in the isolates and were resistant to ciprofloxacin $(66.67 \%)$, levofloxacin (88.9), or both $(55.56 \%)$. These results contrast with the findings of Hossain et al. [25] that $K$. oxytoca strains harboring $q n r A, q n r A$ with $q n r B$, and $q n r B$ with $q n r S$ were highly susceptible to ciprofloxacin $(100 \%)$ and ofloxacin (100\%). In addition, $q n r B$ and $q n r A$ were the most prevalent genes (37.50\%) in $K$. oxytoca strains isolated from pet turtles in Korea [26]. In this study, all isolates demonstrated capacity to transfer $q n r S$ to an $E$. coli recipient. Literak et al. [27] found that qnrS genes were carried by plasmids of the N, X1, and X2 incompatibility groups and were transferable by conjugation to E. coli and/or Salmonella spp. This could support 
Table-3: Characteristics and antimicrobial resistance profiles of Klebsiella oxytoca isolated from slaughtered pigs in Thailand.

\begin{tabular}{|c|c|c|c|}
\hline Pattern of resistance genes & Total (\%) & Pattern of antimicrobial resistance & Total $(\%)$ \\
\hline bla $a_{\text {CTX-M }}$ & $42(68.85)$ & $\begin{array}{l}\text { AP-ATH } \\
\text { AP-ATH-GM } \\
\text { AP-ATH-GM-AK } \\
\text { AP-ATH-GM-AK-NI } \\
\text { AP-ATH-CIP } \\
\text { AP-ATH-AUG-NI-CIP-TM } \\
\text { AP-ATH-GM-CTX-CPM } \\
\text { AP-ATH-GM-NI-CIP } \\
\text { AP-ATH-GM-NI } \\
\text { AP-ATH-CTX-AK } \\
\text { AP-ATH-T-CIP } \\
\text { AP-ATH-AK } \\
\text { AP-ATH-FOT } \\
\text { AP-ATH-C } \\
\text { AP-ATH-LEV } \\
\text { AP-FOT } \\
\text { AP } \\
\text { ATH }\end{array}$ & $\begin{array}{l}10(16.39) \\
8(13.11) \\
6(9.84) \\
3(4.92) \\
2(3.28) \\
1(1.64) \\
1(1.64) \\
1(1.64) \\
1(1.64) \\
1(1.64) \\
1(1.64) \\
1(1.64) \\
1(1.64) \\
1(1.64) \\
1(1.64) \\
1(1.64) \\
1(1.64) \\
1(1.64)\end{array}$ \\
\hline bla ${ }_{\mathrm{CTX}-\mathrm{M}}+q n r S$ & $8(13.11)$ & $\begin{array}{l}\text { AP-ATH-GM-T } \\
\text { AP-ATH-GM-CPM-T-CIP-LEV } \\
\text { AP-ATH-GM-AK-CAZ-T-CIP } \\
\text { AP-ATH-CPM-T-CIP-LEV } \\
\text { AP-ATH-GM-T-CIP-LEV } \\
\text { AP-ATH-GM-AK }\end{array}$ & $\begin{array}{l}2(3.28) \\
2(3.28) \\
1(1.64) \\
1(1.64) \\
1(1.64) \\
1(1.64)\end{array}$ \\
\hline$b / a_{\mathrm{TEM}}+b l a_{\mathrm{CTX}-\mathrm{M}}$ & $6(9.84)$ & $\begin{array}{l}\text { AP-ATH } \\
\text { AP-ATH-GM-AK } \\
\text { AP-ATH-GM-AK-PTZ }\end{array}$ & $\begin{array}{l}4(6.55) \\
1(1.64) \\
1(1.64)\end{array}$ \\
\hline$b / a_{\mathrm{TEM}}+b l a_{\mathrm{CTX}-\mathrm{M}}+q n r S$ & $1(1.64)$ & AP-ATH-GM-AK & $1(1.64)$ \\
\hline bla $_{\mathrm{CTX}-\mathrm{M}}+q n r B$ & $1(1.64)$ & AP-ATH-GM-AK-T-LEV & $1(1.64)$ \\
\hline $\begin{array}{l}\text { bla }{ }_{\text {TEM }}+q n r S \\
\text { qne } S\end{array}$ & $\begin{array}{l}2(3.28) \\
1(1.64)\end{array}$ & $\begin{array}{l}\text { AP-ATH-LEV } \\
\text { AP-ATH-AK-CIP-LEV }\end{array}$ & $\begin{array}{l}2(3.28) \\
1(1.64)\end{array}$ \\
\hline
\end{tabular}

$\mathrm{AP}=$ Ampicillin, $\mathrm{ATH}=$ Azithromycin, $\mathrm{GM}=$ Gentamicin, $\mathrm{AK}=$ Amikacin, NI=Nitrofurantoin, $\mathrm{CIP}=$ Ciprofloxacin, AUG=Amoxicillin/clavulanic acid, TM=Trimethoprim, CPM=Cefepime, FOT=Fosfomycin, C=Chloramphenicol, LEV=Levofloxacin, T=Tetracycline, CAZ=Ceftazidime, PTZ=Piperacillin-tazobactam

that qnrS-carrying K. oxytoca in the current study may have carried the $q n r S$ genes on plasmids.

This study found that some qnrS, qnrS with $b l a_{\text {СTX-M }}$, and $q n r S$ with $b l a_{\text {TEM }}$ genes were transferred to $E$. coli recipients. However, most of the $b l a_{\mathrm{CTX}-\mathrm{M}}$ in $K$. oxytoca donors were not transferred to recipient $E$. coli cells. On the contrary, Zhang et al. [23] reported that the $b l a_{\text {СТX-M }}$ and $b l a_{\text {TEM }}$ genes were successfully transferred from K. oxytoca to E. coli 600. This difference may be because $b l a_{\text {СТХ-M }}$ genes may be located on chromosomes or nonconjugative plasmids. Thus, the characterizations to understand the origin, evolution, and spread of antimicrobial resistance genes are required for further investigation using whole-genome analysis.

\section{Conclusion}

$b l a_{\text {СТX-M-1 }}$ and $q n r S$ were the predominant resistance genes in K. oxytoca strains isolated from slaughtered pigs in Thailand. Further study and ongoing efforts are necessary to develop a complete understanding of the epidemiology, risk factors, transmission dynamics, and public health implications associated with food animals as reservoirs of antimicrobial-resistant bacteria.

\section{Authors' Contributions}

$\mathrm{PB}$ and $\mathrm{AK}$ : Contributed to conceptualization and design of the study. NP: Performed the laboratory work. PB, PC, and RH: Performed validation. SN: Analyzed and interpreted the data. PB: Prepared and wrote the original draft. PB and AK: Reviewed and edited the manuscript. All authors read and approved the final manuscript.

\section{Acknowledgments}

This study was funded by the Kasetsart University Research and Development Institute, Kasetsart University, Bangkok, Thailand. The authors thank Dr. Thanida Harintharanon for providing pig swabs and samples from the slaughterhouses.

\section{Competing Interests}

The authors declare that they have no competing interests.

\section{Publisher's Note}

Veterinary World remains neutral with regard to jurisdictional claims in published map and institutional affiliation. 


\section{References}

1. Kiratisin, P., Apisarnthanarak, A., Laesripa, C. and Saifon, P. (2008) Molecular characterization and epidemiology of extended-spectrum-lactamase-producing Escherichia coli and Klebsiella pneumoniae isolates causing health care-associated infection in Thailand, where the CTX-M family is endemic. Antimicrob. Agents Chemother., 52(8): 2818-2824.

2. Morris, D., O'Hare, C., Glennon, M., Maher, M., CorbettFeeney, G. and Cormican, M. (2003) Extended-spectrumlactamases in Ireland, including a novel enzyme, TEM-102. Antimicrob. Agents Chemother., 47(8): 2572-2578.

3. EFSA Panel on Biological Hazards. (2011) Scientific opinion on the public health risks of bacterial strains producing extended-spectrum $\beta$ lactamases and/or AmpC $\beta$-lactamases in food and food-producing animals. EFSA J., 9(8): 2322.

4. The Center for Disease Dynamics, Economics, and Policy. Resistance Map. (2021) Available from: https://resistancemap.cddep.org/antibioticresistance.php Retrieved on 28-07-2021.

5. Zhao, W.H. and Hu, Z.Q. (2013) Epidemiology and genetics of CTX-M extended-spectrum $\beta$-lactamases in gram-negative bacteria. Crit. Rev. Microbiol., 39(1): 79-101.

6. Ohnishi, M., Okatani, A.T., Harada, K., Sawada, T., Marumo, K., Murakami, M., Sato, R., Esaki, H., Shimura, K., Kato, H. and Uchida, N. (2013) Genetic characteristics of CTX-M-typeextended-spectrum- $\beta$-lactamase (ESBL)-producing Enterobacteriaceae involved in mastitis cases on Japanese dairy farms, 2007 to 2011. J. Clin. Microbiol., 51(9): 3117-3122.

7. Donati, V., Feltrin, F., Hendriksen, R.S., Svendsen, C.A., Cordaro, G., García-Fernández, A., Lorenzetti, S., Lorenzetti, R., Battisti, A. and Franco, A. (2014) Extendedspectrum-beta-lactamases, AmpC beta-lactamases and plasmid mediated quinolone resistance in Klebsiella spp. from companion animals in Italy. PLoS One., 9(3): e90564.

8. Hooper, D.C. (2003) Mechanisms of quinolone resistance. Drug Resist. Updat., 2(1): 38-55.

9. Jacoby, G.A., Strahilevitz, J. and Hooper, D.C. (2015) Plasmid-mediated quinolone resistance. Microbiol. Spectr., 2(5): $1-24$.

10. Ferreira, J.C., Penha Filho, R.A., Kuaye, A.P., Andrade, L.N., Junior, A.B. and da Costa Darini, A.L. (2018) Identification and characterization of plasmid-mediated quinolone resistance determinants in Enterobacteriaceae isolated from healthy poultry in Brazil. Infect. Genet. Evol., 60(2018): 66-70.

11. Phetburom, N., Boueroy, P., Chopjitt, P., Hatrongjit, R., Akeda, Y., Hamada, S., Nuanualsuwan, S. and Kerdsin, A. (2021) Klebsiella pneumoniae complex harboring mor-1, mcr-7, and mcr-8 Isolates from Slaughtered Pigs in Thailand. Microorganisms, 9(12): 2436.

12. Abbott, S. (2011) Klebsiella, Enterobacter, Citrobacter, Serratia, Plesiomonas, and other Enterobacteriaceae. In: Versalovic, J., Carroll, K.C., Funke, G., Jorgensen, J.H., Landry, M.L. and Warnock, D.W., editors. Manual of Clinical Microbiology. 10 $0^{\text {th }}$ ed., Vol. 2. ASM Press, Washington, DC. p639-657.

13. Chander, Y., Ramakrishnan, M.A., Jindal, N., Hanson, K. and Goyal, S.M. (2011) Differentiation of Klebsiella pneumoniae and $K$. oxytoca by multiplex polymerase chain reaction. Int. J. Appl. Res. Vet. Med., 9(2): 138.
14. Monstein, H.J., Ostholm-Balkhed, A., Nilsson, M.V., Nilsson, M., Dornbusch, K. and Nilsson, L.E. (2007) Multiplex PCR amplification assay for the detection of blaSHV, blaTEM and blaCTX-M genes in Enterobacteriaceae. Apmis., 115(12): 1400-1408.

15. Woodford, N., Fagan, E.J. and Ellington, M.J. (2006) Multiplex PCR for rapid detection of genes encoding CTX-M extended-spectrum $\beta$-lactamases. J. Antimicrob. Chemother., 57(1): 154-155.

16. Ciesielczuk, H., Hornsey, M., Choi, V., Woodford, N. and Wareham, D.W. (2013) Development and evaluation of a multiplex PCR for eight plasmid-mediated quinolone-resistance determinants. Med. Microbiol., 62(12): 1823-1827.

17. Clinical Laboratory Standard Institute. (2021) Performance Standards for Antimicrobial Susceptibility Testing. $31^{\text {st }}$ ed. CLSI document M100-S30. Clinical and Laboratory Standards Institute, Wayne PA.

18. Nordmann, P., Dortet, L. and Poirel, L. (2012) Rapid detection ofextended-spectrum- $\beta$-lactamase-producing Enterobacteriaceae. J. Clin. Microbiol., 50(9): 3016-3022.

19. Mobasseri, G., The, C.S.J., Ooi, P.T. and Thong, K.L. (2019) The emergence of colistin-resistant Klebsiella pneumoniae strains from swine in Malaysia. J. Glob. Antimicrob. Resist., 17(2019): 227-232.

20. Molina, F., López-Acedo, E., Tabla, R., Roa, I., Gómez, A. and Rebollo, J.E. (2015) Improved detection of Escherichia coli and coliform bacteria by multiplex PCR. $B M C$ Biotechnol., 15(1): 1-9.

21. Tsuka, T., Ozaki, H., Saito, D., Murase, T., Okamoto, Y., Azuma, K., Osaki, T., Ito, N., Murahata, Y. and Imagawa, T. (2021) Genetic characterization of CTX-M-2-producing Klebsiella pneumoniae and Klebsiella oxytoca associated with bovine mastitis in Japan. Front. Vet. Sci., 8(2021): 659222.

22. Bobbadi, S., Chinnam, B.K., Nelapati, S., Tumati, S.R., Kandhan, S., Gottapu, C. and Boddu, S.V. (2020) Occurrence and genetic diversity of ESBL producing Klebsiella species isolated from livestock and livestock products. J. Food Saf., 40(1): e12738.

23. Zhang, Y., Zhou, H., Shen, X.Q., Shen, P., Yu, Y.S. and Li, L.J. (2008) Plasmid-borne armA methylase gene, together with blaCTX-M-15 and blaTEM-1, in a Klebsiella oxytoca isolate from China. J. Med. Microbiol., 57(10): 1273-1276.

24. Potz, N.A., Colman, M., Warner, M., Reynolds, R. and Livermore, D.M. (2004) False-positive extended-spectrum $\beta$-lactamase tests for Klebsiella oxytoca strain hyper producing K1 $\beta$-lactamase. J. Antimicrob. Chemother., 53(3): 545-547.

25. Hossain, S., De Silva, B.C., Dahanayake, P.S. and Heo, G.J. (2020) Phylogenetic relationships, virulence and antimicrobial resistance properties of Klebsiella sp. isolated from pet turtles in Korea. Lett. Appl. Microbiol., 70(2): 71-78.

26. Stock, I. and Wiedemann, B. (2001) Natural antibiotic susceptibility of Klebsiella pneumoniae, K. oxytoca, K. planticola, K. ornithinolytica and K. terrigena strains. J. Med. Microbiol., 50(5): 396-406.

27. Literak, I., Dolejska, M., Janoszowska, D., Hrusakova, J., Meissner, W., Rzyska, H., Bzoma, S. and Cizek, A. (2010) Antibiotic-resistant Escherichia coli bacteria, including strains with genes encoding the extended-spectrum beta-lactamase and QnrS, in waterbirds on the Baltic Sea coast of Poland. Appl. Environ. Microbiol., 76(24): 8126-8134. 